\title{
Substantiation of Orchard Establishing Projects With Various Planting Patterns
}

\author{
Medelyaeva Z.P.* \\ Economics in Agro-Industrial Complex \\ Voronezh State Agrarian University named after Emperor \\ Peter the Great \\ Voronezh, Russia \\ E-mail: medelaeva@mail.ru \\ Ershova N.V. \\ Department of Land Cadastre \\ Voronezh State Agrarian University named after Emperor \\ Peter the Great \\ Voronezh, Russia \\ E-mail: i.ershova@mail.ru
}

\author{
Nozdracheva R.G. \\ Fruit and Vegetable Growing \\ Voronezh State Agrarian University named after Emperor \\ Peter the Great \\ Voronezh, Russia \\ E-mail: r.nozdracheva@mail.ru
}

\author{
Gorlanov S.A. \\ Department of Economics in Agro-Industrial Complex \\ Voronezh State Agrarian University named after Emperor \\ Peter the Great \\ Voronezh, Russia \\ E-mail: gor_sa@agroeco.vsau.ru
}

\begin{abstract}
Many regions of the Russian Federation have laid a course for developing horticulture and nursery gardening. In many respects, this became possible due to the increased support of agricultural producers from the state in the form of subsidies at the stage of establishing of orchards and nurseries. Subsidies are provided for establishing of perennial fruit and berryproducing shrubs, fruit and berry shrub nurseries, as well as for expenditures connected with caring for perennial fruit and berryproducing shrubs before coming into commercial fruiting. Establishing of orchards is a labor-intensive process that requires substantiation of the varietal composition of fruit crops (winter, summer, and autumn), planting patterns, and cultivation technologies, as well as the calculation of labor, material and monetary costs. The authors have compiled and calculated technological charts for various planting patterns of apple trees placement in the orchard and substantiated the costs for the following periods: soil preparation, orchard planting, and caring for the young and fruit-bearing orchard. The performed calculations indicate that apple production in the conditions of the Central Chernozem Region of the Russian Federation can be highly profitable and depends on the density of plantings in the orchard, cultivation technology, early maturity capabilities, and cropping capacity of cultivars.
\end{abstract}

Keywords - horticultural industry; establishing of apple orchard; efficiency of fruit production; state support; subsidies.

\section{INTRODUCTION}

The development of Russian horticultural industry is one of the priorities of the state agrarian policy [1]. Sanctions imposed against the Russian Federation by the EU countries and the USA, as well as retaliatory measures taken by Russia, necessitated an accelerated development of horticultural industry.

The actual horticultural production currently does not provide the population of the country with proper volumes of fruits. For instance, to meet the needs of the population only of
Voronezh Oblast, it is necessary to produce more than 220 thousand tons of fruits in accordance with medical standard rate of consumption.

In recent years the government has paid increased attention to the domestic production of fruits, subsidizing part of the costs of commodity producers for orchard establishing and caring, as well as providing loans at low interest rates and reimbursing part of capital costs for the construction of modern fruit storage facilities with a controlled gas environment $[2,3]$.

According to the estimates of the Ministry of Agriculture of the Russian Federation, in order to fully provide the country's population with fruits in the coming years, it is necessary to set up to 250 thousand hectares of orchards, including 140 thousand hectares of apple orchards, 24 thousand hectares of pear orchards, 60 thousand hectares of stone fruit orchards, and 18 thousand hectares of berry plantations, subject to the availability of modern storage facilities in horticultural enterprises $[4,5]$.

As far as it is known, the industry under discussion has specific features associated with the mismatch of the project financing period and recovery of products. Apple orchards come into commercial fruiting on the $3^{\text {rd }}-5^{\text {th }}$ year, and the maximum gross yield of apples can be obtained on the $9^{\text {th }}-11^{\text {th }}$ year after the orchard establishment. Therefore, the volume of imported apple fruits remains significant, although there is a downward trend. The main suppliers of apples to Russia are Moldova, Serbia, and Belarus. In 2019 it was planned to purchase 710 thousand tons of apples and 253 thousand tons of pears in foreign countries, which is respectively by 80 and 5 thousand tons less than in 2018 .

Preliminary figures indicate that the volume of apple production in Russia in 2019 amounted to 1.7 million tons (in farms of all categories), which is 100 thousand tons more than in 2018. 
According to expert opinion, with the current pace of state support for horticultural commodity producers quantity of imports of apples can be significantly reduced by 2026 . The official estimates published by the Fruit and Vegetable Union show that 16 thousand hectares of intensive-type orchards were established in Russia in 2018, and about 11.5 thousand hectares in 2019 [6, 7].

Depending on the capabilities of each particular horticultural enterprise (farm) in Russia, they establish the orchards of the following types:

1) conventional orchards with a spherical shape of tree crowns and moderately dense placement (416-660 trees per 1 ha) on moderate and vigorous rootstock without stakes;

2) orchards with flat tree crowns and dense placement (660-800 trees per $1 \mathrm{ha}$ ) on moderate rootstock without stakes;

3 ) orchards with spindle-shaped tree crowns and highly dense placement (660-1000 trees per 1 ha) on moderate rootstock without stakes;

4) orchards on dwarf rootstock with stakes and dense placement of trees (800-1250 trees per 1 ha) forming a tiered, freely growing palmette;

5) orchards on dwarf rootstock (1250-5000 trees per 1 ha) with stakes and tree crowns shaped as a slim spindle $[8,9]$.

Since 2014 the gardeners of the Central Chernozem Region have been significantly increasing the area of newly set-up orchards, including those of intensive type. As for Voronezh Oblast, its horticulture and nursery gardening are currently being revived on the basis of production intensification (see Table I).

TABLE I. ESTABLISHING OF ORCHARDS AND NURSERIES IN VORONEZH OBLAST BY YEARS*

\begin{tabular}{|c|c|c|c|c|}
\hline \multirow{2}{*}{ Year } & \multicolumn{4}{|c|}{ Area, hectare } \\
\cline { 2 - 5 } & $\begin{array}{c}\text { Total } \\
\text { area }\end{array}$ & $\begin{array}{c}\text { fruit and berry- } \\
\text { producing shrubs }\end{array}$ & $\begin{array}{c}\text { orchards of } \\
\text { intensive } \\
\text { type }\end{array}$ & $\begin{array}{c}\text { fruit and } \\
\text { berry shrub } \\
\text { nurseries }\end{array}$ \\
\hline 2008 & 309 & 265 & 17 & 27 \\
\hline 2009 & 297 & 158 & 104 & 35 \\
\hline 2010 & 177 & 138 & 11 & 28 \\
\hline 2011 & 422 & 214 & 191 & 17 \\
\hline 2012 & 710 & 113 & 597 & - \\
\hline 2013 & 579 & 42 & 537 & - \\
\hline 2014 & 593 & 26 & 559 & 8 \\
\hline 2015 & 420 & 37 & 365 & 49 \\
\hline 2016 & 701 & 103 & 548 & 38 \\
\hline 2017 & 917 & 239 & 639 & 220 \\
\hline Total & 5,125 & 1,335 & 3,568 & \\
\hline
\end{tabular}

a. *According to figures provided by the Department of Agrarian Policy of Voronezh Oblas Administration

Establishing of orchards requires the availability of Russian-made zoned planting material. However, the nursery gardening industry in Voronezh Oblast is developing slowly, and there is a noticeable shortage of high-quality planting material of pomiferous cultures, stone fruit, and berry crops for establishing of orchards of intensive type [11, 12]. The majority of experts believe that currently it is necessary to promote the preservation of research and technological groundwork (it is important not to lose already created cultivars) and initiate the civilized development of the planting material market.

According to figures provided by the Ministry of Agriculture of the Russian Federation establishing of 1 hectare of conventional orchard of intensive-type orchard and of super-intensive type orchard costs on average 180-200 thousand rubles, more than 1 million rubles and 2-3 million rubles respectively. The level of state support also varies, e.g. subsidies amount to 55 thousand rubles per 1 hectare for establishing of a conventional orchard, and to 250 thousand rubles for establishing of an intensive-type orchard (more than 800 trees per $1 \mathrm{ha}$ ).

Defining a development strategy, including the one for horticulture, requires substantiating all production and financial parameters, on the basis of which it would be possible to talk about the feasibility of implementing a specific project $[13,14]$.

It should also be borne in mind that federal and regional budget allocations do not cover all the costs of horticultural producers and that in order to obtain subsidies it is necessary to justify the costs connected with orchard establishing and caring both for young plants, and fruit-bearing plants.

\section{RESULTS AND DISCUSSION}

The objective of research was to compare the material and monetary costs of orchard establishing depending on the density of planting of apple trees in intensive-type orchards.

The information base of research included the official statistical materials of the Federal State Statistics Service of the Russian Federation and its territorial authority in Voronezh Oblast, the Ministry of Agriculture of the Russian Federation, the Department of Agrarian Policy of Voronezh Oblast Administration, production and financial plans, and annual reports of agricultural producers (business and financial performance indicators), for which the production of fruits and berries is the main field of activity.

The authors have performed an economic substantiation of projects for establishing of orchards of various patterns grouping the costs by the following types of activities: orchard planting, caring for a young orchard, and caring for a fruitbearing orchard. For this purpose technological charts were used. The costs were calculated for different planting patterns: $1.000 ; 1.250 ; 3.600$ trees per 1 hectare.

Seedlings for orchard planting are being purchased mainly from third parties and cost 230-250 rubles per piece, so the cost of apple tree planting material varies greatly depending on the planting pattern, e.g. when from 1.000 to 3.600 trees are planted per 1 hectare (see Table II).

The cost of seedlings to be planted at the density of 3.600 trees per 1 hectare is 3.6 times higher than at the density of 1.000 trees per 1 hectare. In all the patterns the cost of seedlings has the largest share in total costs and ranges from $43 \%$ (when 1,000 trees are planted per 1 ha) to $67 \%$ (when 3.600 trees are planted per 1 ha). 
TABLE II. COST OF ESTABLISHING OF ORCHARDS WITH VARIOUS PLANTING PATTERNS

\begin{tabular}{|l|c|c|c|}
\hline \multicolumn{1}{|c|}{ Indicator } & $\begin{array}{c}\text { Soil } \\
\text { preparation }\end{array}$ & $\begin{array}{c}\text { Orchard } \\
\text { planting }\end{array}$ & Total \\
\hline \multicolumn{4}{|c|}{ 1,000 trees planting pattern } \\
\hline Total costs, RUB000's per 1 ha & 152.9 & 413.1 & 576.0 \\
\hline Cost of seedlings & - & 250.0 & 250.0 \\
\hline \multicolumn{4}{|c|}{ 1,250 trees planting pattern } \\
\hline Total costs, RUB000's per 1 ha & 151.0 & 430.0 & 531.0 \\
\hline Cost of seedlings & - & 312.5 & 312.5 \\
\hline \multicolumn{4}{|c|}{ 3,600 trees planting pattern } \\
\hline Total costs, RUB000's per 1 ha & 152.3 & 1030.3 & 1350.5 \\
\hline Cost of seedlings & - & 900.0 & 900.0 \\
\hline
\end{tabular}

The costs of preparing the soil for orchard establishing are almost equal and, according to our estimates, amount to about 160.0 RUB000's for preparing 1 hectare of land. The costs of planting of 1 hectare of orchard are 118-130 RUB000's not including the cost of seedlings.

As it follows from the data in Table II, the costs increase with an increase in the number of trees according to the planting pattern due to the increase in the cost of seedlings. The number of seedlings also influences other cost items. For instance, the costs of labor with deductions, petroleum products, and maintenance of fixed assets are growing. The total costs of orchard planting can range from 531 to 1.030 RUB000's per 1 hectare.

If an intensive-type orchard is established with trellising, then material and monetary costs increase, i.e. about 400 RUB000's is needed per 1 hectare of orchard. For more details on the costs of establishing of intensive orchard by cost items see Table III (we give an example of 3,600 trees per 1 ha planting pattern).

TABLE III. COST OF ESTABLISHING OF 1 HECTARE OF ORCHARD

\begin{tabular}{|c|c|c|c|}
\hline \multirow[b]{2}{*}{ Cost items, RUB000's } & \multicolumn{3}{|c|}{ Amount } \\
\hline & $\begin{array}{c}\text { Soil } \\
\text { preparation }\end{array}$ & $\begin{array}{l}\text { Orchard } \\
\text { planting }\end{array}$ & Total \\
\hline Cost of plantings & & 900.0 & 900.0 \\
\hline Wages & 3.9 & 88.8 & 92.7 \\
\hline $\begin{array}{l}\text { Social insurance } \\
\text { contributions }\end{array}$ & 1.2 & 25.2 & 26.4 \\
\hline Fertilizers & 90.5 & - & 90.5 \\
\hline Plant protection agents & 3.6 & 15.4 & 19.0 \\
\hline Petroleum products & 7.2 & 139.2 & 146.4 \\
\hline Water & 0.5 & 3.1 & 3.6 \\
\hline $\begin{array}{l}\text { Maintenance of fixed assets } \\
\text { a) amortization }\end{array}$ & 2.7 & 24.5 & 27.2 \\
\hline b) routine maintenance & 2.1 & 11.3 & 13.4 \\
\hline Electrical energy & 0.2 & 6.5 & 6.7 \\
\hline Other costs & 0.9 & 23.4 & 24.3 \\
\hline Total & 112.8 & $1,237.4$ & $13,550.2$ \\
\hline
\end{tabular}

In the planting pattern presented in Table III the costs per 1 hectare will amount to 112.8 RUB000's for soil preparation and to 1237.4 RUB000's for orchard planting.

The bulk of root system of the most of fruit trees develops in the soil layer at the depth of $70-80 \mathrm{~cm}$, and quite significant mass of the roots goes even deeper into the subsurface layers. Therefore, in order to upgrade the survival ability of nursery transplants and their further growth, as well as to increase the productivity of trees, it is necessary to prepare the soil in an appropriate manner. Such soil preparation is called deep cultivation. Thus, pre-planting soil treatment consists in formation of deep root layer with an improved structure and an increased level of fertility. Regardless of the density of orchard planting pattern, soil treatment and tillage are performed according to conventional technologies adopted in the Central Chernozem Region.

The costs of caring for a young orchard prior to fruiting consist of the costs of soil preparation, orchard planting, and caring for the apple plantings. These costs form the amount that will be taken into account in product costing in the form of depreciation charges.

When caring for a young apple orchard for 3-4 years, it is annually planned to apply mineral fertilizers at the rate of $13.5 \mathrm{~kg}$ per 1 hectare. Besides, in order to protect trees and shrubs from diseases and pests, they should be treated with various crop protection agents

Different chemical or biological substances can be used in protection plants from diseases (e.g. fungicides) and animal pests (e.g. insecticides). Currently, there are many various products for protection orchards on the market. Right on time fulfilled first spring pest control is a key moment in the successful protection of the garden from harmful insects and mites. As with the protection of the garden from diseases, treatment from pests is also confined to certain phenological stages, and they can be combined in tank mixtures. The only exception is substances intended exclusively for protection against mites (acaricides) which should be applied separately as they are not compatible with other means of protection. All other insecticides and fungicides can be mixed in one sprayer and applied simultaneously. Such combined treatments save both time and finances.

The orchard trees and berry shrubs can be treated by lowvolume and multi-volume spraying with various crop protection agents, e.g. Horus, WDG; Kosaid, WDG; Skor, EC; Actara, SC; Prestige, SC, and others.

According to our estimates, during the growing season it is necessary to perform an average 8 treatments of apple trees with protective agents, the total costs of which can be 45-50 RUB000's per 1 hectare.

Just as in a young apple orchard, caring for plantings in a fruit-bearing orchard involves watering with simultaneous fertilization with mineral fertilizers, but in a fruit-bearing orchard the number of treatments with protective agents against diseases and pests increases to 10 , and the costs of harvesting increase significantly.

The total costs per 1 hectare of a young and a fruit-bearing orchard are presented in Table IV.

The costs in an intensified orchard over 15 years are presented in Table V (we give an example of 3.600 trees per 1 ha planting pattern).

Costs distribution by years is as follows:

- soil preparation accounts for $1.5 \%$ of the total;

- orchard planting and caring for a young orchard on the $2^{\text {nd }}$ year account for $12.2 \%$ of the total; 
- caring for a young orchard during the $3^{\text {rd }}-4^{\text {th }}$ year accounts for $3.6 \%$ of the total (1.8\% annual);

- caring for a fruit-bearing orchard during the $5^{\text {th }}-15^{\text {th }}$ year accounts for $82.7 \%$ of the total $(\approx 5.5 \%$ annual $)$.

TABLE IV. COSTS OF CARING FOR A YOUNG AND A FRUIT-BEARING ORCHARD (ANNUALIZED)

\begin{tabular}{|c|c|c|c|c|c|c|}
\hline \multirow{3}{*}{$\begin{array}{c}\text { Cost items, } \\
\text { RUB000's } \\
\text { per } 1 \text { ha }\end{array}$} & \multicolumn{6}{|c|}{ Density of plantings in the orchard } \\
\hline & \multicolumn{2}{|c|}{$\begin{array}{l}1,000 \text { trees } \\
\text { per } 1 \text { ha }\end{array}$} & \multicolumn{2}{|c|}{$\begin{array}{l}1,250 \text { trees } \\
\text { per } 1 \text { ha }\end{array}$} & \multicolumn{2}{|c|}{$\begin{array}{c}3,600 \text { trees } \\
\text { per } 1 \text { ha }\end{array}$} \\
\hline & 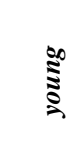 & 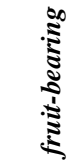 & 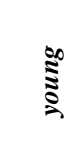 & 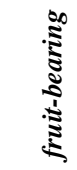 & 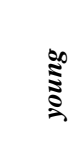 & : \\
\hline Direct costs, total & 146.6 & 277.6 & 175.5 & 481.8 & 220.1 & 710.2 \\
\hline Wages & 33.8 & 91.9 & 32.2 & 166.2 & 59.8 & 340.6 \\
\hline $\begin{array}{l}\text { Social insurance } \\
\text { contributions }\end{array}$ & 10.8 & 21.7 & 7.5 & 53.2 & 19.1 & 109.0 \\
\hline Fertilizers & 23.4 & 18.0 & 24.3 & 18.0 & 24.9 & 17.3 \\
\hline $\begin{array}{l}\text { Plant protection } \\
\text { agents }\end{array}$ & 44.9 & 53.3 & 46.1 & 53.3 & 49.8 & 58.1 \\
\hline
\end{tabular}

TABLE V. ESTABLISHING OF ORCHARDS AND NURSERIES IN VORONEZH OBLAST BY YEARS*

\begin{tabular}{|c|c|c|c|c|}
\hline \multirow[b]{3}{*}{ Indicators } & \multicolumn{4}{|c|}{ Year } \\
\hline & $1^{s t}$ & $2^{\text {nd }}$ & $3^{r d}-4^{\text {th }}$ & $5^{\text {th }}-15^{\text {th }}$ \\
\hline & 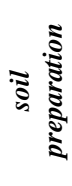 & 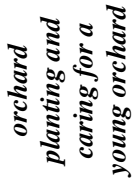 & 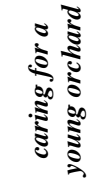 & 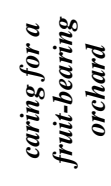 \\
\hline Soil preparation & 1.5 & - & - & - \\
\hline Orchard planting & - & 12.2 & - & - \\
\hline $\begin{array}{l}\text { Caring for a } \\
\text { young orchard }\end{array}$ & - & - & 3.6 & - \\
\hline $\begin{array}{l}\text { Caring for a fruit- } \\
\text { bearing orchard }\end{array}$ & - & - & - & 82.7 \\
\hline
\end{tabular}

The coming into the fruiting season depends on the type of orchard, the selected apple cultivars, rootstock, and planting density (planting pattern). These characteristics determine the useful life of the orchard (15-20 years), which is taken into account when calculating the depreciation charges for fixed assets, which include the fruit-bearing orchard.

It is supposed to use an intensive orchard for 15-17 years, if it is established on dwarf rootstock, or up to 25-30 years for a conventional orchard, which increases the depreciation charges and hence, the production cost.

Table VI presents the results of calculation of production cost with the account of the planned yield and current costs for the production of apples including the depreciation on orchard establishment.

When the production cost of standard and non-standard apples is determined, costs are distributed proportionally to the cost of each type of product at sales prices. The calculations show the costs of standard apples, which make up $95 \%$ of the total gross harvest. The estimated production cost calculated by direct costs per 1 centner of apples will be 1.360 rubles.
These costs will be supplemented with the costs of organizing production and management in the enterprise in the amount of $20 \%$ of direct costs (76.5 RUB000's) and the cost of fruit storage amounting to $25 \%$ of production costs (direct and overhead costs; 116.1 RUB000's). Taking into account the mentioned costs, the production cost of 1 centner of apples will increase to 2.036 rubles.

TABLE VI. CALCULATION OF PRODUCTION COST OF 1 CENTNER OF APPLES

\begin{tabular}{|l|c|c|c|}
\hline \multicolumn{1}{|c|}{ Indicator } & $\begin{array}{c}\text { Amount } \\
\text { of product, c }\end{array}$ & $\begin{array}{c}\text { Production } \\
\text { cost, RUB000's }\end{array}$ & $\begin{array}{c}\text { Per 1 c of } \\
\text { product, } \\
\text { rubles }\end{array}$ \\
\hline $\begin{array}{l}\text { Direct production } \\
\text { costs }\end{array}$ & 285 & 387.6 & $1,360.0$ \\
\hline Overhead costs & & 76.5 & 268.42 \\
\hline Storage costs & & 116.0 & 407.02 \\
\hline Sales costs & & 116.0 & 407.02 \\
\hline Total & 285 & 696.1 & $2,442.46$ \\
\hline
\end{tabular}

Selling of apples is also accompanied by costs associated with transportation, loading, labor remuneration, rental of commercial premises, advertising, etc. An increase in production costs by commercial costs determines the total cost of production. According to our calculations, commercial costs will amount to $20 \%$ and the total cost of 1 centner will be 2.442 rubles.

The estimated production cost and planned wholesale price (4.500 rubles per $1 \mathrm{c}$ ) will provide a positive financial result to apple producers within all planting patterns (see Table VII).

TABLE VII. PROFITABILITY OF APPLE FRUIT PRODUCTION DEPENDING ON THE DENSITY OF ORCHARD PLANTING

\begin{tabular}{|l|c|c|c|}
\hline \multirow{2}{*}{ Indicator } & \multicolumn{3}{|c|}{$\begin{array}{c}\text { Planting pattern, } \\
\text { trees per 1 ha }\end{array}$} \\
\cline { 2 - 4 } & $\mathbf{1 . 0 0 0}$ & $\mathbf{1 . 2 5 0}$ & $\mathbf{3 . 6 0 0}$ \\
\hline Profit per 1 centner, rubles & 680 & 720 & 768 \\
\hline Profitability, \% & 16.5 & 18.6 & 22.0 \\
\hline
\end{tabular}

A relatively low profitability of fruits at dense planting is explained by high costs of caring for the trees per 1 hectare (e.g. installation of trellises, pruning, and harvesting), and high depreciation charges due to the reduced useful life of the orchard.

In Voronezh Oblast 21 specialized enterprises are engaged in fruit and berry production. Five of them are large agricultural enterprises, for which the production of fruits and berries is the main field of activity. Three horticultural farms (ZAO "Central Chernozem Fruit and Berry Company" in Novousmansky District, ZAO "Ostrogozhsksadpitomnik" in Ostrogozhsky District, and OOO "Novonadezhdinskoye" in Anninsky District) are among the TOP-10 largest fruit producers in the Russian Federation in terms of production volumes [10].

In the course of research the authors also compared their own calculated data with the actual costs of material and monetary resources per 1 hectare of orchard plantings and the production cost of 1 centner in the main fruit-growing enterprises of Voronezh Oblast and the whole region for the period from 2016 to 2018 (see Table VIII). 
TABLE VIII. COSTS OF MATERIAL AND MONETARY RESOURCES AND PRODUCTION COST OF APPLES IN THE LEADING ENTERPRISES OF VORONEZH OBLAST

\begin{tabular}{|l|c|c|c|c|}
\hline \multirow{2}{*}{\multicolumn{1}{|c|}{ Enterprises }} & \multicolumn{3}{|c|}{$\begin{array}{c}\text { Production cost per 1 c, } \\
\text { rubles }\end{array}$} & $\begin{array}{c}\text { Costs per 1 ha, } \\
\text { RUB000's }\end{array}$ \\
\cline { 2 - 5 } & $\mathbf{2 0 1 6}$ & $\mathbf{2 0 1 7}$ & $\mathbf{2 0 1 8}$ & $\mathbf{2 0 1 8}$ \\
\hline OOO "Novonadezhdinskoye" & 1.741 & 1.687 & 992 & 175.8 \\
\hline $\begin{array}{l}\text { ZAO “Central Chernozem } \\
\text { Fruit and Berry Company" }\end{array}$ & 1.140 & 3.158 & 1.125 & 272.7 \\
\hline $\begin{array}{l}\text { ZAO } \\
\text { "Ostrogozhsksadpitomnik" }\end{array}$ & 1.082 & 1.880 & 1.183 & 524.5 \\
\hline Voronezh Oblast, total & 1.079 & 7.475 & 1.037 & 195.0 \\
\hline
\end{tabular}

In 2017 the high production cost of fruits in the region as a whole was caused by the low yield in many enterprises where horticulture was not the leading industry (except ZAO “Ostrogozhsksadpitomnik").

The calculations performed by the authors and other experts have shown the efficiency of establishing nurseries and selling the planting material in the conditions of Krasnodar Krai, the Central Chernozem Region and Voronezh Oblast [15, 16].

It must be noted that subsidizing the costs of planting perennial fruit and berry shrub plantations, intensive orchards (at least 800 trees per 1 hectare), fruit and berry shrub nurseries is provided if agricultural commodity producers have a project for orchard establishing and caring. This is why the presented calculations gain practical importance and can be used by specialists of various agricultural enterprises in their activities.

The authors also performed calculations of the efficiency of growing two-year-old seedlings on vegetatively reproduced rootstocks, indicating the feasibility of producing planting material in fruit nurseries in the region. The organization of transplant production in fruit nurseries will increase the output of sturdy planting material (seedlings and cuttings), as well as will accelerate the establishing of intensive orchards with highquality transplants of well-proven cultivars. It is necessary to shut out bad-faith producers and sellers of poor-quality planting material from the gardeners, setting the development of the planting material market under civilized laws.

The use of various technologies for plant reproduction (seedling and clonal rootstocks) and growing of planting material of pomiferous cultures, stone fruit, and berry crops will not only increase the efficiency of the horticultural industry, but also foster the growth of employment of the rural population. The creation of new jobs will ensure year-round employment of rural citizens, thereby mitigating the seasonality of labor use in the Agro-Industrial Complex.

\section{CONCLUSION}

The production of pomicultural products in the Central Chernozem Region can become profitable if new intensive orchards are established and state support is provided to agricultural commodity producers.

Providing subsidies will increase the profitability of the production and the interest of the producers in annual establishment of orchards in order to increase the production of high-quality fruits, as well as in increasing the areas for planting material in nurseries in Voronezh Oblast.

At the same time, an accelerated development of horticultural industry will exert an impact not just on the indicators of economic efficiency, but also on other types of efficiency (e.g. social and environmental) that are manifested in the creation of jobs, and the development of rural territories.

\section{References}

[1] Challenges and development prospects of horticultural industry in the Russian Federation. Retrieved from: http://council.gov.ru/activity/activities/parliamentary/103534/

[2] Reference book on measures and directions of state support for the Agro-Industrial Complex of the Russian Federation. Voronezh Oblast. Retrieved from: http://www.gp.specagro.ru/ region/3529/2/13/6/2019

[3] "On approval of the procedure of granting of subsidies from the regional budget to agricultural commodity producers (except citizens managing private farm holding) for reimbursement of part of the costs for establishing and caring for perennial fruit and berry shrub plantations". Voronezh Oblast Government Decree, 07 February 2018, no. 111. Retrieved from: https://yandex.ru/search/ ?clid=2186621\&text

[4] L.V. Grigoreva, "Biological growth peculiarities of the cuttings of various rootstocks in a horizontal nursery", Int. J. of Pharmac. Res. and Allied Sci., vol. 10, no. 4, pp. 632-640, October-December 2018.

[5] Developmental trend in horticulture in Russia. Retrieved from: http://www.agbz.ru/articles/tendentsii-razvitiya-sadovodstva-v-rossii

[6] I.M. Kulikov, I.A. Minakov, "Problems of providing the population of Russia with fruit and berry products and solutions to them", AIC: Econ., Manag., vol. 4, pp. 66-76, 2017.

[7] The current status of horticulture in Russia. Retrieved from: http://sadisibiri.ru/sad-ross-kachalkin.html.

[8] B.S. Gegechkori, Innovative technologies in fruit growing. Study guide. Krasnodar: Krasnodar State Agrar. Univer.y, 2014.

[9] L.V. Grigoreva, "Intensive technologies in horticulture as the basis of its development when joining the WTO", Bull. of Michurinsk State Agrar. Univer., vol. 3, pp. 49-53, 2012.

[10] Z.P. Medelyaeva, R.G. Nozdracheva, "Economic efficiency of orchard establishment and apple production in the conditions of Voronezh Oblast", Vest. of Voronezh State Agrar. Univer., vol. 12, no. 2(61), pp. 216-223, 2019.

[11] Analysis of the status and prospective directions of development of nursery gardening and horticulture. Retrieved from: https://rosinformagrotech.ru/data/elektronnye-kopii-izdanij/ raste nievodstvo/send/5-rastenievodstvo/1358-analiz-sostoyaniya-i-perspektiv nye-napravleniya-razvitiya-pitomnikovodstva-i-sadovodstva-2019.

[12] K.S. Ternovykh, N.V. Leonova, E.D. Kuznetsova, Priorities for enhancement of economic efficiency of horticultural industry. Voronezh: Voronezh State Agrar. Univer., 2019.

[13] A.V. Agibalov, Y.V. Tkacheva, L.A. Zaporozhtseva, "Improvement of the financial management strategy for agricultural enterprises", Int. J. of Econ. Perspect., vol. 11, no. 3, pp. 1686-1696, 2018.

[14] V.G. Zakshevskiy, I.F. Khitskov, O.G. Charykova, Strategic directions for agricultural development in Voronezh region. Voronezh: Res. Instit. of econ. and organizat. of Agro-Industr. Complex of the Central BlackSoil Area of Russ., 2017.

[15] S.A. Gorlanov, Z.P. Medelyaeva, V. B.Malitskaya, M.B. Chirkova, E.I. Kostyukova, "Content analysis the term "effectiveness" and the concepts of its quantitative characteristics", Indo Amer. J. of Pharmac. Sci., vol. 6, no. 3, pp. 5293-5298, 2019.

[16] Yu.V. Plugatar, A.V. Smykov, "Prospects for the development of horticulture in Crimea", Works of the State Nikitsky Botanical Garden, Yalta, vol. 140, pp. 5-18, 2015. 